\title{
THE INTEGRITY OF DISCOURSE IN THE ANGLICAN EUCHARISTIC TRADITION: A CONSIDERATION OF PHILOSOPHICAL ASSUMPTIONS
}

\begin{abstract}
This article explores the integrity of the discourse in the Anglican eucharistic tradition by considering the philosophical assumptions that underlie eucharistic theology. It argues that where the conversation of the Anglican eucharistic tradition is open and unfinished then the integrity of the discourse is facilitated as opposed to the conversations of party positions and particular interests which suggest exclusive versions of truth. The conversation or dialogue of Anglican eucharistic theology is seen to be enhanced through the consideration of the philosophical assumptions of realism and nominalism to both the moderate and immoderate degrees that underpin eucharistic theology as a state of affairs. The insights of contemporary philosophers are used as a way of conceptualising the discourse of the Anglican eucharistic tradition and a model of Anglican eucharistic theology is suggested as a means of facilitating the integrity of the discourse through the recognition of multiformity in the tradition and by distancing the discourse from the hermeneutic idealism of particular interest.
\end{abstract}




\section{THE INTEGRITY OF DISCOURSE}

In his book On Christian Theology, Rowan Williams asks an important question for Christian theology, that is: 'What makes us say of any discourse that it has or that it lacks “integrity”?'.1 Williams argues that 'usually we can answer this in terms of whether such a discourse is really talking about what it says it is talking about'.2 This answer is not as deceptively simple as might appear at first glance. For instance, a discourse without integrity might well not be talking about what it says it is talking about because it deceptively conceals its true agenda and presents a set of positions and arguments operating on two levels, one acknowledged and one not. Such a discourse 'is one which steps back from the risks of conversation', 3 that is, not allowing critical and reflective subject to subject conversation and dialogue. True conversation recognizes that the conversation is unfinished, and allows for the possibility of correction. A closed, predetermined or exclusive discourse or conversation, often typical of church parties 4 fails to acknowledge the true interests of the participants and presents 'to the hearer a set of positions and arguments other than those that are finally determinative of its working'.5

\section{THE DISCOURSE OF THE ANGLICAN EUCHARISTIC TRADITION}

Douglas6 and Lovat and Douglas7 have examined the discourse of the Anglican eucharistic tradition through exploration of ways of knowing in Anglican eucharistic theology. Here significant use is made of the critical theorist and philosopher Jurgen Habermass $\quad 9$ and his theory of communicative action as a means of examining the integrity of the discourse. Lovat and Douglas10 argue that some within the Anglican tradition base their discourse on what McCarthy, interpreting Habermas, calls 'hermeneutic idealism', 11 that is: 
conceptualising of reality that is totally dependent on one's own (or one's 'communal groups') beliefs, values and interpretations, whilst at the same time remaining blind to their causes, backgrounds and those wider connections that would contextualise them and help those holding them to see that they are in fact just one set of beliefs, values and interpretations in a sea of related and unrelated sets.12

Where hermeneutic idealism remains the focus of the Anglican eucharistic tradition the integrity of the discourse is threatened.

This article argues that the integrity of the tradition can be enhanced by consideration of the multiformity of the philosophical assumptions underlying Anglican eucharistic theology, functioning as an essential feature of the tradition and distancing the discourse from hermeneutic idealism. Some practise hermeneutic idealism in presenting exclusive views that, in effect, claim more of the 'truth' for their party interest than do others in the discourse. In certain instances, this practice leads to the further claim that alternative views actually have no legitimacy in the discourse of Anglican eucharistic theology, e.g. Doyle 13 from an Anglican Evangelical position and Silk14 from an Anglican Catholic position. Such prosecution of hermeneutic idealism casts doubt over the integrity of the discourse of Anglican eucharistic theology when it operates on the basis of a party position or interest alone, or on the basis of power rather than genuine conversation and dialogue. How then can integrity be recovered? Williams argues that 'integrity can be recovered ... to the extent that [those involved in the discourse] show themselves capable of conversation'.15 This article therefore seeks to facilitate conversation through an examination of the multiformity of philosophical assumptions underlying Anglican eucharistic theology in the hope that this will facilitate the type of dialogue of which Williams16 and Habermas 1718 speak and in so doing enhance the integrity of the discourse in the Anglican eucharistic tradition. 
Douglasi9 and Lovat and Douglas20 argue that the discourse of the Anglican eucharistic tradition should be one of dialogue amidst difference and describe ‘a Habermasian breakthrough’ where the multiform system of Anglican eucharistic theology is seen to be composed of more than one lifeworld or technical or hermeneutic interest. In applying a Habermasian framework to the discourse of Anglican eucharistic theology, they argue that 'there is no one position that should be allowed the privilege of being hermetically sealed within its own solipsism and so denied the potential for inter-subjective understanding'.21 Douglas22 argues that the discourse of Anglican eucharistic theology is essentially multiform revolving around the distinction between the philosophical assumptions of 'realism' and 'nominalism', both positions moderated by a 'moderate' and 'immoderate' form. This article seeks to explore these philosophical assumptions and their relationship to Anglican eucharistic theology in an effort to facilitate the discourse of that tradition.

\section{REALISM AND NOMINALISM}

The distinction between realism and nominalism operates within the larger philosophical question of the problem of universals. This distinction is the focus of significant contemporary secular philosophical reflection, undertaken by philosophers such as Michael Loux and David Armstrong, but has generally not been widely associated with Anglican eucharistic theology in the modern era.

Loux distinguishes realists and nominalists in the following way:

Realists claim that where objects are similar or agree in attribute, there is some one thing that they share or have in common; nominalists deny this. Realists call these shared entities universals; they say that universals are entities that can be simultaneously exemplified by several different objects; and they claim that universals encompass the properties things possess, the relations into which they enter, and the kinds to which they belong.23 
Indeed, Loux argues that there are 'objective similarities among things' and that such a claim is 'not a claim born of any metaphysical theory'.24 Rather, such a claim can be described as 'a pre-philosophical truism' and as such 'one that has given rise to significant philosophical theorising'. The whole issue goes back, argues Loux, to the origins of metaphysics itself and concerns 'whether there is any general explanation for the pre-philosophical truism that things agree in attribute'.25

Differences exist between those who adopt a realist view. Whereas Plato and subsequently, Augustine speak of things participating in a divine or eternal Form, others such as Aristotle and Aquinas, say that things 'instantiate', 'exhibit' or 'exemplify' a single property, quality or attribute. Even though the terms differ, Loux argues that these philosophers are called 'metaphysical realists’ or just realists. Metaphysical realists distinguish between two types or categories of objects, namely, particulars and universals.

Nominalists however:

deny that there are universals; and the central motivation for their view is the belief that our metaphysics should exhibit simplicity of theory. [Nominalists] believe that it is possible to provide fully satisfactory accounts of attribute agreement, subjectpredicate discourse, and abstract reference that posits only particulars or individuals.26

There are also different forms of nominalism. Loux says that: 'The most extreme version endorses an ontology incorporating only particulars and holds that all claims apparently about universals are just disguised ways of making claims about concrete particulars'.27 Other philosophers find serious difficulties with this austere or immoderate version of nominalism and so 'endorse a metalinguistic form of nominalism. This view agrees that the only things that exist are concrete particulars, but holds that claims apparently about universals are really disguised ways of talking about linguistic expressions'.28 
The distinction between realism and nominalism in relation to the discourse of Anglican eucharistic theology centres on whether or not there is any linking in a real way between particulars and universals, referred to here as 'signs' (the particulars of bread and wine and their offering in the Eucharist) and 'signified' (the universal - Christ's body and blood, the sacrifice of Christ or the nature of Christ). Whereas realists argue that signs and signified are linked in a real way, that is, sacramental signs instantiate, or are an instance of the signified, nominalists deny this, arguing that any categories of classification (like instantiation) are optional and unconstrained by any pre-existent kinds of properties in the world apart from propositional thinking and semantic structures. These philosophical assumptions impact on eucharistic theology in that acceptance of a realist theology implies acceptance of the sacramental principle, that is, God is seen to use signs or things of this world such as bread and wine, to convey or to contain the signified: things of a divine nature such as the nature of Christ's body and blood. Nominalists, on the other hand, deny realism and the sacramental principle, and argue that knowledge of a divine reality occurs by rational and semantic propositionalism, principally reflection on the preaching and hearing of the text of Scripture, without any realist linking or instantiation of sign and signified. For these nominalists sacraments functions only as promises and assurances of grace, mediated by faith alone, and not as instruments or vehicles of grace. All this centres around what is known as the 'problem of universals'. The problem of universals has been considered in depth by the modern secular philosopher, David Armstrong29 3031 and this article seeks to explore his work in relation to the Eucharist in an effort to understand the multiformity of the philosophical assumptions underlying the Anglican eucharistic tradition and in so doing to enhance the integrity of the discourse of the tradition by avoiding the solipsism of hermeneutic idealism. 
For Armstrong, 'the problem of universals is the problem of how numerically different particulars can nonetheless be identical in nature, all be of the same "type"'.32 Armstrong has two main lines of argument for the existence of objective universals. The first line of argument (realism) is that many different particulars can all have what appears to be the same nature. There is, according to Armstrong, such a thing as identity of nature.з3 The second line of argument (nominalism) concerns the identification of universals with many different meanings, arguing that there is therefore a movement from meaningful general words to the existence of universals. Nominalism relies heavily on semantic propositionalism. This second line of argument Armstrong sees as unsound, since a theory of universals must precede the semantics of general terms. Nominalism, heavily based on semantics, says Armstrong, fails to do this.34 For Armstrong, universals, described as properties and relations, cannot be identified with semantic notions such as propositional predicates, concepts or resemblances. The acceptance of this argument represents for Armstrong 'an emancipation of the theory of universals from the theory of semantics' 35 and leads to an acceptance of objective universals that cannot exist independently of particulars. This line of thinking underpins a view of eucharistic theology based on realism.

Armstrong also distinguishes between those who hold 'moderate' and 'immoderate' views of both nominalism and realism.36 Moderate nominalism, argues Armstrong, admits properties and relations but takes them to be particulars, capable of semantic and cognitive analysis, rather than universals. Moderate realism admits properties and relations but takes them to be universals. It brings the universals down to earth in an immanent way, into space-time. Universals in moderate realism are therefore capable of multiple location, being found wherever the particulars that instantiate the universals are found.37 Immoderate nominalists substitute predicates, concepts, classes and resemblances for properties and relations. They do not 
admit the existence of universals but only particulars, each of which is a selfenclosed entity, related only by the semantic and cognitive analyses, such as predicates, concepts and resemblances that apply to the particulars. Immoderate realists express a Platonic realism where earthly particulars may participate in eternal Forms. The Platonic view of immoderate realism results in two realms - a realm of universals and a realm of particulars universals in 'heaven' and particulars in space-time. Universals and particulars, in immoderate realism, are therefore separated, with particulars participating in the universals as Divine Forms. The universals, for Plato, are therefore transcendent in immoderate realism, with instantiation implying a relation between universals and particulars (participation) that crosses between the two realms ss such that the universal participates in the particular in a strict or numerical sense. Armstrong considers each of these alternatives and rejects both immoderate nominalism and immoderate realism since he believes they are implausible.39 He sees some plausibility in moderate nominalism 40 but opts for moderate realism as the most plausible solution to the problem of universals 41 in what he terms a 'state of affairs'.

\section{NATURE AND IDENTITY}

Armstrong in his discussion of realism uses the terms 'identity' and 'nature'. In relation to 'nature' he says: 'It is an intelligible possibility that there should be two particulars with exactly the same nature'.42 By 'nature', Armstrong means the 'single, all embracing spatio-temporal system' 43 such that 'to speak of the nature of a thing ... is to speak of the properties of that thing'.44 There can be two particulars, a piece of paper and a pen, but each can share exactly the same nature, that is, the property 'white', such that there is white paper and a white pen and the relation 'on the table', since both are on the table. Armstrong argues that: 'It is universals [properties and relations] that give a thing its nature, kind or sort' ${ }^{45}$ Universals are therefore 
strictly identical in their different instantiations46 since a universal can be instantiated in more than one particular. Armstrong also says that: 'The demand that universals be strictly identical in their different instances, the 'powerful truism', entails that for two instantiations of the same universal, the sameness of type involved must be strict identity'.47 Despite the differences between particulars (the paper and the pen), the universal property 'white' and the universal relation 'on the table', are strictly identical, even though the particulars, that is, the paper and the pen, are not strictly identical. It is the strict identity of the universal that is implied in moderate realism whereas it is the strict identity of the particular with the universal that is implied in immoderate realism.

Further, in regard to 'identity’, Armstrong says: 'Different particulars may be (wholly or partially) identical in nature',48 although he argues there are two senses of the word 'identity'. There is, he says, 'identity in nature' and 'numerical identity'.49 The paper and the pen are identical in nature, in that they both have the property 'white' and both stand in the relation 'on the table', but they are not numerically identical since a piece of paper is not strictly identical with a pen even though they share the same property 'white' and the same relation 'on the table'. Identity in nature is akin to loose identity and numerical identity is akin to strict identity.

\section{RELATIONAL AND NON-RELATIONAL REALISM}

Numerical identity (or strict identity) Armstrong describes as 'relational realism', where 'particularity and universality are related constituents of particulars'.50 In the example being used, numerical identity could only exist where the particularity of paper and the property 'white' are related constituents of a pen. Paper cannot, however, be a constituent of a pen. Armstrong rejects such a union and argues for identity in nature (loose 
identity) or what he describes as 'non-relational realism'. He says: 'What is required is some more intimate union between the particularity and universality of particulars than mere relation. We require a non-relational form of immanent realism'.51 This ‘non-relational realism’ acknowledges that different things, for example, a piece of paper and a pen, lack a numerical identity in that a piece of paper is not strictly identical with a pen, but it also acknowledges they nonetheless share the same property, that is, they are both white, and stand in the same relation, that is, they are both on the table. Non-relational realism therefore does not require strict identity of particulars even though the properties or relations, that is, universals, may be strictly identical. Armstrong concludes, 'such identity in nature is literally inexplicable, in the sense that it cannot be further explained'.52

David Ford has argued in much the same way in his discussion of what happens in the Eucharist.53 Here Ford argues that the identity between bread and wine of the Eucharist and Christ's body and blood is not relational or strict realism but non-relational or loose realism, that is, the bread and wine of the Eucharist instantiates the nature of Christ, such that the nature of Christ is strictly identical in both instantiations of bread/wine and body/blood, but that the particulars of bread and wine of the Eucharist are not strictly or numerically identical with the particulars of Christ's body and blood, even though both particulars (bread/wine and body/blood) instantiate the same universal (the nature of Christ). Relational realism, on the other hand, implies a fleshy or immoderate presence and sacrifice of Christ in the Eucharist, where bread and wine and their offering and Christ's body and blood and sacrifice are seen as strictly identical. A eucharistic theology therefore based on relational realism would mean that Christ is present in the Eucharist in a fleshy, bloody or carnal manner, where the bread and wine literally becomes flesh and blood and where Christ is re-sacrificed on the altar in the Eucharist. This has also been called 'immoderate realism'.54 
Non-relational or moderate realism on the other hand implies a non-fleshy presence of Christ's nature in the Eucharist, where bread and wine and Christ's body and blood possess a loose identity, both instantiating the nature of Christ.55 It should be noted that, even though some Anglican theologians, such as Ford, accept moderate (non-fleshy) realism, more generally immoderate (fleshy) realism is not accepted by Anglican theologians. This distinction between moderate and immoderate realism in relation to the Eucharist is important if the integrity of Anglican eucharistic theology is to be facilitated, since this distinction helps to clarify what is meant and what is not meant by the real presence of Christ in the Eucharist. Appreciating this distinction helps to avoid the accusation of immoderate or fleshy realism that is sometimes made by Anglican Evangelicals56 in the discussion of the real presence of Christ in the Eucharist (moderate or non-relational realism) accepted by some Anglican Catholics.57 Using the philosophical distinctions of moderate and immoderate realism limits the hermeneutic idealism of particular church parties or individuals since it provides a wider view of the multiformity of Anglican eucharistic theology and as such helps to give the discourse of the Anglican eucharistic tradition greater integrity than the mere prosecution of party interest.

\section{STATES OF AFFAIRS}

Armstrong, in his discussion of moderate realism, argues for what he calls 'states of affairs'. He says that 'a state of affairs involves both particulars and universals and exists if and only if a particular has a property or, instead, a relation holds between two or more particulars.

The properties and relations are universals, not particulars'.58 Armstrong argues, however, that, 'we should think of the world as a world of states of affairs, with particulars and universals only having existence within states of affairs'.59 States of affairs are seen as the 'fundamental tie between particulars and universals'.60 
Armstrong distinguishes a 'factualist' position from a 'thingist' position. It is Armstrong's contention that a 'thingist' position has dominated Western philosophy based on a substance/attribute distinction, inherited from Aristotle, where substance was seen as being capable of independent existence.61 This is the basis of Aquinas' notion of transubstantiation in the Eucharist, discussed in his Summa Theologica,62 where the substance of Christ's body and blood is present in bread and wine with the outward appearance of bread and wine remaining as the accidents. Armstrong argues, however, that properties are not like things. Properties exist as entities, not things. Properties are the way things are.63 Accordingly, Armstrong's aim 'is to defend a version of Factualism, that is, to defend an ontology of facts or states of affairs'.64 He says that: 'A philosophy that admits both particulars and universals ought to admit states of affairs (facts), which have particulars and universals as constituents (not parts)' .65 This means that:

\footnotetext{
The Aristotelian realism about universals defended [by Armstrong] ... brings universals, properties and relations, within states of affairs. The states of affairs, organised as they are organised, in turn constitute the whole of reality (space-time if the thesis of Naturalism is accepted). Given these universals, the world is unified in a way that it is not unified in Nominalist ontology. Identities run across the states of affairs.66
}

In a state of affairs, particulars instantiate universals as properties and relations, e.g. a particular piece of paper instantiates the property 'white' and a particular pen instantiates the relation 'on the table'. Armstrong asks, however, 'Why recognise states of affairs?' and 'Why not recognise simply particulars, universals (properties and relations) and instantiation of universals by particulars?'.67 Armstrong sets out his argument for recognising states of affairs in the following abstract way: if $a$ (a particular) is $F$ (a universal), then $a$ exists and $F$ exists. $a$ being $F$ therefore involves something more than $a$ and $F$. There is something more than what Armstrong describes as the fundamental tie or nexus of instantiation. The 
existence of $a$ and $F$ and the instantiation does not amount to $a$ 's being $F$ (i.e. $a$ could exist and $F$ could exist yet it fails to be the case that $a$ is $F$, e.g. $F$ is instantiated but not in $a$ ). The something more must be $a$ 's being $F$. This 'being' is a state of affairs,68 dependent on moderate realism and identity in nature, or loose identity. Armstrong's argument can be expressed more concretely in terms of the example given above in this way: a particular piece of paper instantiates the universal white, so the particular piece of paper exists and the universal white exists. The particular piece of paper being an instantiation of the universal white involves something more than the particular piece of paper and the universal white. There is something more than the fundamental tie or nexus of instantiation. The existence of the particular piece of paper and the universal white and the instantiation of 'white' in the particular piece of paper does not amount to pieces of paper being white (i.e. the particular piece of paper could exist and the universal white could exist, yet it fails to be the case that the particular piece of paper is white, e.g. being white is instantiated but not in the particular piece of paper in that another piece of paper could be another colour). The something more must be pieces of paper being white. It is whatever this 'being' is that is a state of affairs. All this depends on the distinction between what Armstrong calls ‘nature' and 'identity'. This distinction will now be considered again in relation to the Eucharist.

\section{NATURE AND IDENTITY IN THE EUCHARIST}

In relation to the Eucharist, using Armstrong's philosophical reflection and following the line of argument suggested by Ford,69 the following moderate realist analysis of what happens in the Eucharist can be made. Bread and wine and the body and blood of Christ can have the same nature (Christ's identity of nature) without having a strict or numerical identity. This means that bread and wine can have Christ's identity of nature without being the 
particular of his literal flesh and blood. This suggests that Christ's identity of nature is something more than either flesh/blood or bread/wine. The two (bread and wine on the one hand and body and blood on the other) in such a moderate realist analysis, share the same nature, that is, Christ's identity of nature. The universal, Christ's identity of nature, it must be emphasised is strictly identical in both instantiations, but the particulars are not. This means nothing more than that Christ's identity of nature is in both instantiations of bread and wine and body and blood. Care needs to be taken in using the terms 'nature' and 'identity'. Nature has the sense of a loose identity, or identity in nature. There are therefore two senses in which Armstrong uses 'identity’. There is 'identity in nature’ (loose) and 'numerical identity' (strict). Where the word 'identity' is used in relation to the particulars of the Eucharist, it must be clearly differentiated whether 'loose' or 'strict' identity is meant. In the case of moderate realism, identity in nature (loose) is meant (the universal, Christ's nature, is present in both particulars of bread/wine and body/blood) and in the case of immoderate realism, numerical identity (strict) is meant, where both particulars are seen as being identical (e.g. bread and wine is literally Christ's body and blood). This latter form of realism, immoderate realism, is generally rejected by the Christian tradition.

In the Eucharist, therefore, bread and wine being the body and blood of Christ is not simply a matter of strict identity, in that bread and wine are in some way the fleshy body and blood of Christ, but more a matter of loose identity or identity in nature, where both particulars, bread and wine on the one hand and Christ's body and blood on the other, instantiate the universal, that is, Christ's nature. Interpreting Armstrong, this means that the Eucharist in such a realist analysis is described as a state of affairs, acting as the fundamental tie between the particulars and the universal. In a critical sentence, Armstrong says: 'identities run across states of affairs'.70 This 
means that the universal, Christ's identity of nature, runs across the state of affairs that is the Eucharist and that there is an identity in nature between the different particulars of the Eucharist. This is the argument put by Ford 71 when he speaks of non-relational realism and where he distinguishes between an immoderate form of realism (i.e. Christ being present in the bread and wine in a fleshy and bloody manner) and a moderate form of realism (i.e. Christ being present in the particulars of the Eucharist in nature but not in a fleshy or bloody manner).

\section{STATES OF AFFAIRS AND THE EUCHARIST}

Armstrong's analysis72 can be applied to the Eucharist with the consequent recognition of the Eucharist as a state of affairs. Following Armstrong's line of argument and inserting relevant details, the argument runs as follows in relation to bread and wine and the nature of Christ: If bread and wine (each a particular) is (that is, instantiates) Christ's identity of nature (a universal), then bread and wine exist and the nature of Christ exists. Note that the word 'is’ refers to identity of nature (moderate realism) and not numerical identity (immoderate realism). Bread and wine being Christ's identity of nature therefore involves something more than bread and wine and the nature of Christ. There is something more than what Armstrong describes as the fundamental tie or nexus of instantiation. The existence of bread and wine and Christ's identity of nature does not amount to bread and wine being Christ (i.e. bread and wine could exist and the nature of Christ could exist yet it fails to be the case that bread and wine is the nature of Christ, e.g. the nature of Christ is instantiated but not in bread and wine as indeed it was in the person of Jesus and as it can be in the Word and the Church as the body of Christ). The something more must be bread and wine being Christ's identity of nature (just as it could be said that the something more is the Word or the Church being Christ's identity of nature). This is a state of 
affairs. This means that in any realist argument, bread and wine being the nature of Christ is the state of affairs called the Eucharist. This argument expresses therefore a moderate realist theology of the Eucharist.

The argument Armstrong 73 uses can be applied to the Eucharist as a state of affairs. Following Armstrong's line of argument and inserting the relevant details the argument runs as follows in relation to bread and wine and the nature of Christ: Let it be the case that particular bread and wine instantiates the universal, Christ's identity of nature. Bread and wine is Christ's identity of nature. Note that 'is' indicates identity in nature (moderate realism), not numerical identity (immoderate realism). Must there not be something about the world that makes it to be the case, that serves as an ontological ground for this truth? The truthmaker or ground, as Armstrong calls it, cannot be bread and wine, at any rate if bread and wine are taken as the thin particular, the particular apart from its properties. Can it be the pair bread and wine and the nature of Christ? This is getting a little warmer. But what appears to be the decisive argument against this suggestion is that it is possible that bread and wine and the nature of Christ should exist and yet bread and wine not be the nature of Christ. The nature of Christ may be instantiated elsewhere. The nature of Christ is instantiated, for example, in the body and blood of Christ, in Scripture and in the eucharistic celebration and assembly, as well as in bread and wine. It is therefore being asked what in the world will ensure, make true, underlie, serve as the ontological ground for, the truth that bread and wine is Christ's identity of nature. The obvious candidate seems to be the state of affairs bread and wine being Christ's identity of nature, just as it could be Word being Christ's identity of nature or the eucharistic assembly being Christ's identity of nature. In the state of affairs 'bread and wine being Christ's identity of nature' bread and wine and the nature of Christ are brought together in an immanent realist manner where the particulars (bread and wine) instantiate the universal (the nature of Christ). 
Armstrong it can be concluded therefore that the truthmaker argument for states of affairs can be accepted. This article suggests that the truthmaker argument for the Eucharist as a state of affairs can also be accepted, although it needs to be pointed out that Armstrong nowhere accepts this argument specifically in relation to the Eucharist. This application of Armstrong's truthmaker argument to the Eucharist in a moderate realist manner is, however, a contribution to the continuing conversation of the Anglican eucharistic tradition since it explores the underlying philosophical assumptions of the tradition in a way that facilitates an understanding of the multiformity of the tradition and in so doing enhances the integrity of the discourse.

\section{THE QUESTION OF TRUTH}

The question of 'truths' is an important one for Armstrong. He puts the following case:

consider the truth that $a$ is hot and that $a$ 's molecules are in more or less violent motion. The two statements are surely not the same statement: the difference in their meaning ensures that here we have two different truths. Yet we do not have here two different states of affairs. ... So two truths with only one truthmaker.74

Truthmakers (states of affairs or their constituents) therefore entail truths.

Truth therefore attaches in the first place to propositions that have a truthmaker.75

\section{Armstrong concludes therefore:}

When we say that the world is a world of states of affairs, and when we say that it is a spatio-temporal system, we are describing the one world in two different ways, ways that are linguistically and conceptually to a degree orthogonal to each other but which describe the one realm, a realm which is truthmaker for the true statements in both vocabularies. The hypothesis I advance is that the description of reality in terms of states of affairs is, if rather abstract, ontologically more fundamental. The description in terms of a spatio-temporal system is, undoubtedly, much more accessible epistemically and conceptually. But the two descriptors are describing the same reality.76 
The question of 'truths' is vital in this argument and is used here in relation to the Eucharist. In the Eucharist we have more than one truth or instantiation. The particulars of bread and wine and the body and blood of Christ are two truths which instantiate the universal, the nature of Christ. The presence of Christ in the reading of the Scriptures, in the eucharistic celebration and assembly are other truths which also instantiate the same universal, the nature of Christ. There are several instantiations yet there is only one state of affairs - the Eucharist in which the universal, Christ's nature, is known. There is more than one truth but there is only one truthmaker.77 Truthmakers (states of affairs and their constituents) therefore entail truths, called an instantiation. Truth therefore in the first place attaches to propositions that have a truthmaker.78 The truthmaker argument for the Eucharist can be a state of affairs based on moderate realist assumptions and the witness of the Anglican eucharistic tradition can be used to assist in making this judgment. The work of Douglas79 $\quad{ }^{80}$ shows that moderate realism and moderate nominalism are features of Anglican eucharistic theology from the Reformation to the present, and that both immoderate realism and nominalism are not generally features of that theological tradition. These findings have relevance to the integrity of the discourse in the Anglican eucharistic tradition since it helps to establish that there is more than one philosophical assumption underlying the tradition. The philosophical assumptions underlying Anglican eucharistic theology include both nominalism and realism and the immoderate and moderate degrees help to distinguish between what are features of the tradition and what are not. To deny the multiformity of the Anglican eucharistic tradition and to be content with hermeneutic idealism limits the integrity of the discourse since it remains in the realm of particular and party interest alone.

It must be realised that the above argument depends on the acceptance of a realist analysis, such as Armstrong proposes. At the same time, it also needs 
to be recognised that within the discourse of the Anglican eucharistic tradition there are those who do not accept realism in relation to eucharistic theology. The distinction between realism and nominalism within the discourse of the Anglican eucharistic tradition has been explored by Douglas.81 ${ }^{82}$ For theologians who do not accept realism, signs are not seen to be linked with the signified, nor is the sacramental principle accepted.83 For those within the Anglican eucharistic tradition who accept such a nominalist analysis, truthmakers dependent on realism, as well as universals and the idea of Christ's identity of nature are not accepted as philosophical assumptions (e.g. Doyle84 and comments by Douglas85). In such a nominalist analysis as Doyle presents, bread and wine on the one hand and Christ's body and blood on the other hand are both particulars, without any realist identity in nature and without any talk of universals and states of affairs being necessary to explain how the world is. The value of Armstrong's work for the Anglican eucharistic tradition is that a consideration of both of these positions, realism and nominalism, is described and that the way each operates in moderate and immoderate degrees is considered. Consideration of both realism and nominalism in the Anglican eucharistic tradition, to both moderate and immoderate degrees, may therefore not only help in understanding the multiformity of theological opinion within the Anglican tradition, but may also exclude what has not been a part of the tradition and in addition promote conversation in the tradition that moves past the exclusivity of hermeneutic idealism.

\section{A THEORETICAL MODEL OF THE ANGLICAN EUCHARISTIC TRADTION}

In an effort to assist in this conversation and in providing integrity for the discourse of the Anglican eucharistic tradition, and with the insights of 
philosophers such as Armstrong in mind, the following theoretical model of the Anglican eucharistic tradition was proposed by Douglas.86

\begin{tabular}{|c|c|}
\hline $\begin{array}{c}\text { Immoderate } \\
\text { Realism }\end{array}$ & $\begin{array}{c}\text { Moderate } \\
\text { Realism }\end{array}$ \\
\hline $\begin{array}{c}\text { Immoderate } \\
\text { Nominalism }\end{array}$ & $\begin{array}{c}\text { Moderate } \\
\text { Nominalism }\end{array}$ \\
\hline
\end{tabular}

Figure 1: A Theoretical Model of the Anglican Eucharistic Tradition

Each of the quadrants of the theoretical model of the Anglican eucharistic tradition is discussed below.

Moderate Realism: a philosophical notion referring to identity of nature or loose identity as philosophers such as Armstrong call it. This means that the sign instantiates the signified in a loose way, that is, identity of nature, rather than as strict identity. In the terms of eucharistic theology this means that the signs of bread and wine, for example, instantiate the nature of Christ as Word or logos, in much the same way that the person of Jesus instantiated the nature of Christ as Word or logos (John 1:14). Jesus therefore instantiated the nature of Christ as a person on earth and the bread and wine of the Eucharist instantiate the nature of Christ as well. In terms of eucharistic sacrifice this means that the nature of Christ's sacrifice is instantiated in the Eucharist by a process of dynamic remembrance (known as anamnesis) such that the effects of Christ's sacrifice in the past are instantiated in the Eucharist in the present by means of the eucharistic action. Moderate realist notions of eucharistic presence and sacrifice are frequently found in the eucharistic theology of the Anglican Church, expressed in theological statements and eucharistic liturgies.87 
In moderate realist eucharistic theology the statement: 'This is my body' means that the signs ('this') instantiate the nature of Christ and the signs are the means whereby the benefits of Christ's presence and sacrifice are conveyed to people in the Eucharist. This is sometimes known as the sacramental principle, that is, God working in this world through the things of this world (e.g. bread and wine, or memorial remembrance) in order to convey grace to people by means of these signs. People therefore in consuming the elements of the Eucharist are not receiving real flesh and blood in the their physical or fleshy sense but rather the nature of Christ which is nonetheless real and effective in that the signs convey or are the vehicles of the grace of Christ. John Macquarriess or Christopher Cocksworth 89 would be two contemporary examples of Anglican theologians who adopt a moderate realist eucharistic theology (see case studies in Douglas90).

Immoderate Realism: a philosophical notion referring to strict identity as philosophers such as Armstrong call it. This means that the sign and the signified are strictly identical in every way, physically as well as metaphysically. In terms of eucharistic theology this means that the signs of the Eucharist, the bread and wine, are seen to become the physical, carnal or bloody body and blood of Christ in the sense that real flesh and real blood is on the altar following consecration. In terms of eucharistic sacrifice, immoderate realism would imply that Christ is sacrificed again or really in the Eucharist (a re-immolation of Christ or a re-iteration of Christ's sacrifice in a bloody or fleshy manner). Generally the Roman Catholic and Anglican Churches reject immoderate notions of eucharistic presence or sacrifice.

It is important to note that in any discussion of transubstantiation (as defined by Thomas Aquinas), the notion of a real presence of Christ's presence in the Eucharist and the idea of memorial remembrance as anamnesis, are not 
immoderate realist concepts but moderate realist in the eucharistic theology expressed.

In an immoderate realist eucharistic theology the statement: 'This is my body' means that the signs ('this') become the body and blood of Christ in a fleshy and physical manner such that real flesh and blood (with all the physical characteristics of flesh and blood) are present on the altar in the Eucharist and consumed by the communicant in a gross manner. evidence of an Anglican theologian adopting this position was found by Douglas91 92 although some Anglican theologians such as Doyle93 ${ }^{94}$ suggest that this view is held by some Anglicans and in some eucharistic liturgies.

Moderate Nominalism: a philosophical notion referring to the idea that whatever exists is a particular and nothing but a particular. This means that signs do not instantiate any signified universals since the existence of universals is denied. All that exists are particulars - bread and wine that are used in the Eucharist are one set of particulars and Christ's body and blood which existed in the first century $\mathrm{AD}$ and which no longer exists in that form are another set of particulars. The nature of Christ as a universal notion is therefore not seen to be instantiated in the signs of the Eucharist in a moderate nominalist analysis since the existence of universals is not admitted. The Eucharist therefore is about remembering what happened in the past and receiving the benefits of Christ's presence and sacrifice by faith alone in a propositional manner. The benefits or grace of Christ are not received through any signs on earth even though the sacraments are the context in which the remembering occurs and the grace is received by faith.

In a moderate nominalist eucharistic theology the statement: 'This is my body' means that the signs ('this') signify the body and blood of Christ in a linguistic analysis but do not become the body and blood in either a moderate 
or immoderate realist sense. The particulars (the bread and the wine on one hand and the body and blood of Christ on the other) remain separated entities and the signs of bread and wine are not therefore the vehicles of grace. The presence of any universal (e.g. the nature of Christ, in either a loose or strict sense of identity) is denied and so the sacramental principle is denied in any realist sense, even though the sacraments function as the context for the remembering and the receiving of grace by faith alone. Handley Moule would be an example of an Anglican theologian who adopts a moderate nominalist position in his eucharistic theology (see Douglas95).

Immoderate Nominalism: a philosophical notion referring to the idea that whatever exists is a particular and nothing but a particular. The existence of universals is denied and the idea that signs instantiate the signified is also denied. All that exists are particulars - bread and wine which are used in the Eucharist and Christ's body and blood which existed in the first century AD and which no longer exists in that form and is not instantiated in the signs of the Eucharist. The Eucharist is not the means whereby Christ is remembered by faith since this is only seen to occur through the rational and propositional statements found in the words of Scripture. Whereas moderate nominalism admits that the benefits of Christ's presence and sacrifice are known by faith in the remembering that occurs in the context of the Eucharist, immoderate nominalism does not admit this, and instead argues that the benefits of Christ's can only be known through the words of Scripture96. This knowing through Scripture occurs through the promises of God which Scripture presents as the word is read and proclaimed. Immoderate nominalists therefore deny that there is any presence or sacrifice of Christ in the Eucharist in a realist sense through signs and also deny that the benefits of Christ are known in the Eucharist by a process of remembering as the communicant participates in and receives communion. The benefits of Christ can only be known in an immoderate nominalist analysis through hearing and 
receiving the promises of God that are found in the words of Scripture, proclaimed and preached. The immoderate nominalist therefore rejects the notion of participating in Christ sacramentally (either in the realist sense using the signs which instantiate the signified or in the moderate nominalist sense of by faith alone). God therefore is only seen to work in the world directly through God's word and not sacramentally through signs. Sacraments are therefore seen as something created by people and of a lesser status than the 'word' of Scripture seen to be created by God. Sacraments are therefore signs of God's promises that are known through the word alone and not through sacramental signs. People participate in Christ by faith alone, but this occurs, not through the sacraments, as moderate realism and moderate nominalism suggest, but through the word alone. Robert Doyle (see case study in Douglas97) is an example of a theologian who adopts an immoderate nominalist eucharistic theology.

\section{THE THEORETICAL MODEL IN THE DISCOURSE OF ANGLICAN EUCHARISTIC THEOLOGY}

The use of the model above (Figure 1) suggests that sameness of type (the problem of universals) in the Anglican eucharistic tradition can be analysed in four ways - according to realist and nominalist philosophical assumptions, to both moderate and immoderate degrees. In general Anglican theologians have not used these terms, and the use of the model across the whole of the Anglican eucharistic tradition represents an innovation in describing the Anglican eucharistic tradition. This is perhaps what John Macquarriess has argued is needed as a replacement for the substance metaphysic present in eucharistic theology, with both acceptance and rejection, for so long. The advantage of the model proposed above is that it assists, using contemporary philosophical reflection, the discourse of Anglican eucharistic theology by recognising the multiformity of the tradition and not privileging one 
theological position and its philosophical assumptions over others. At the same time the reality is that moderate realism and moderate nominalism are the prevailing essences of the Anglican eucharistic tradition.99 $\quad 100 \quad$ The potential exists therefore for the Anglican eucharistic tradition to engage in dialogue with the various theological positions and philosophical assumptions without prejudicing the integrity of the discourse by prosecuting hermeneutic idealism. At the same time it needs to be recognised that the functioning of the model depends on the acceptance by participants in the dialogue that multiformity exists in the Anglican eucharistic tradition and that there is a need for subject-to-subject dialogue for any conversation to have integrity. Where such an acceptance is not admitted then dialogue is difficult and the views of particular technical and hermeneutical interests will be privileged over other technical and hermeneutic interests. At the same time, where such an acceptance is not admitted critical interest will also be limited by commitments to these particular and narrow interests and the integrity of the discourse will be threatened.

Rowan Williams argues that for participants in the discourse of Christian theology 'integrity can be recovered ... to the extent that they show themselves capable of conversation'.101 This suggests that dialogue and the recognition of differing interests is an important aspect in theological discourse. Such a process 'makes clear that it accepts, even within its own terms of reference, that there are ways in which it may be questioned and criticized. ... It sets out a possible framework for talk and perception, a field for debate, and so a field for its own future transmutations'.102 The type of religious discourse that Williams speaks of is seen to have integrity since it does not slip into what he describes as 'the total perspective mode', that is, 'declining the attempt to take God's point of view'.103 This suggests that Christian theology, such as Anglican eucharistic theology, in its workings brings the complexity of its human world to judgement before God and does 
not seek to articulate or complete that judgement.104

It is as if the

incompleteness and the openness to further discussion and dialogue bring about the possibility of re-formation and it is this possibility which can give the discourse of Anglican eucharistic theology an honesty and integrity since it turns in on itself and surrenders itself to God.105

This article has argued that Anglican eucharistic theology has integrity when it moves past the hermeneutic idealism which often presents as the one and only valid interpretation, but is in reality merely a feature of party position and interest.106 The discussion of philosophical assumptions underlying Anglican eucharistic theology and the suggestion of a theoretical model of the Anglican eucharistic tradition undertaken above is seen as a way of avoiding this type of hermeneutic idealism which threatens the integrity of the tradition since instead it focuses on the multiformity of the tradition and encourages dialogue rather than exclusive conversation. In turn, this multiformity and its attached conversation reinserts into the discourse of Anglican eucharistic theology the much needed integrity that it lacks when the focus is on party interest alone. 


\section{Notes}

${ }^{1}$ Rowan Williams, On Christian Theology, (Oxford: Blackwell, 2000), p. 3.

2 Ibid., p. 3.

3 Ibid., p. 4.

${ }^{4}$ Terence Lovat and Brian Douglas, 'Dialogue Amidst Difference in Anglican Eucharistic Theology: A Habermasian Breakthrough’, Australian EJournal of Theology, 9 (March, 2007), online at http://dlibrary.acu.edu.au/research/theology/ejournal/aejt_9/lovat.htm ${ }^{5}$ Williams, On Christian Theology, p. 3.

${ }^{6}$ Brian Douglas, Ways of Knowing in the Anglican Eucharistic Tradition: Ramifications for Theological Education (A thesis submitted in fulfilment of the requirements for the degree of Doctor of Philosophy at the University of Newcastle, Australia, 2006).

${ }^{7}$ Lovat and Douglas, 'Dialogue Amidst Difference in Anglican Eucharistic Theology'.

8 Jurgen Habermas, The Theory of Communicative Action. Volume 1. Reason and the Rationalization of Society (trans. T. McCarthy) (Boston: Beacon Press, 1984).

9 Jurgen Habermas, The Theory of Communicative Action. Volume 2. Lifeworld and System: A Critique of Functionalist Reason (trans. T. McCarthy) (Boston: Beacon Press, 1989).

10 Lovat and Douglas, 'Dialogue Amidst Difference in Anglican Eucharistic Theology’.

11 Thomas McCarthy, Translator's Introduction’ in Habermas, J., Theory. Volume 1, p. xxvi.

12 Lovat and Douglas, 'Dialogue Amidst Difference in Anglican Eucharistic Theology'.

13 Robert Doyle, 'Word and Sacrament in Catholic and Evangelical Theology' in Head, I.

(ed),' Who may celebrate? Boundaries of Anglican order. A second publication of the

Doctrine Commission of the General Synod on the Identity of the Eucharistic Presidency or Administrant of Holy Communion (Sydney: The Standing Committee of General Synod of the Anglican Church of Australia, 1996).

14 David Silk, The Holy Eucharist: Alternative and Additional Texts for Use with the Orders of the Eucharist in AAPB and APBA (Authorised and commended by the Bishop of Ballarat under the Constitution of the Anglican Church of Australia, Ballarat: Anglican Diocese of Ballarat, 1st edn 1995 and 2nd edn 2002).

15 Williams, On Christian Theology, p. 4.

${ }_{17}^{16}$ Williams, On Christian Theology.

17 Habermas, The Theory of Communicative Action. Volume 1.

18 Habermas, The Theory of Communicative Action. Volume 2.

Douglas, Ways of Knowing in the Anglican Eucharistic Tradition: Ramifications for Theological Education.

${ }^{20}$ Lovat and Douglas, 'Dialogue Amidst Difference in Anglican Eucharistic Theology'.

21

Lovat and Douglas, 'Dialogue Amidst Difference in Anglican Eucharistic Theology’, p. 9.

22 Douglas, Ways of Knowing in the Anglican Eucharistic Tradition.

${ }^{3}$ Michael Loux, Metaphysics. A Contemporary Introduction (London and New York: Routledge, 2002), p. 20.

24

24 Ibid, p. 21.

25 Ibid, p. 21.

26 Ibid, p. 54.

27 Ibid, p. 54.

28 Ibid, p. 54.

29 David Armstrong, Universals. An Opinionated Introduction (Boulder: Colorado: Westview, 1989). 
30 David Armstrong, Nominalism and Realism. Universals and Scientific Realism. Volume 1 (Cambridge: Cambridge University Press, 1995).

31 David Armstrong, A World of States of Affairs (Cambridge: Cambridge University Press, 1997).

32 Armstrong, Universals. An Opinionated Introduction, p. 41.

33 Armstrong, Nominalism and Realism, p. xiii.

34 Ibid, p. xiv.

35 Ibid, p. 6.

36 Armstrong, Universals. An Opinionated Introduction, pp. xii-xiii.

Ibid, p. 98

38 Ibid, p. 76

39 Armstrong, A World of States of Affairs, p. 22.

40 Armstrong, Universals. An Opinionated Introduction, p. xi.

41 Armstrong, A World of States of Affairs, p. 22.

42 Armstrong, Nominalism and Realism, p. 82.

43 Ibid, p. 138.

44 Ibid, p. 103.

45 Armstrong, Universals. An Opinionated Introduction, p. 94.

46 Armstrong, A World of States of Affairs, p. 27.

47 Ibid, p. 28.

48

Armstrong, Nominalism and Realism, p. 109.

Ibid, p. 111.

50 Ibid, p. 102.

51 Ibid, p. 107.

52 Ibid, p. 109.

53 David Ford, 'What happens in the Eucharist?', Scottish Journal of Theology, 48 (1995), pp. 359-381.

54 Douglas, Ways of Knowing in the Anglican Eucharist Tradition, pp. 145-49.

55 Ibid, pp. 145-49.

56 Robert Doyle, 'Here we offer you a spiritual sacrifice' - an estimate, (Sydney: Anglican Church League, 1995), pp. 2-3, online at http://www.acl.asn.au

57 Doyle's analysis of the eucharistic liturgies of A Prayer Book for Australia suggests that these liturgies represent a return to what he describes as fleshy presence and sacrifice of Christ in the Eucharist.

58 Armstrong, A World of States of Affairs, p. 1.

59 Armstrong, Universals. An Opinionated Introduction, p. 94

60 Armstrong, A World of States of Affairs, p. 118.

61 Ibid, p. 4.

62 Thomas Aquinas, Summa Theologica, Volumes 1-5 (trans. Fathers of the English Dominican Province) (Westminster, Maryland: Christian Classics, 1981).

63 Armstrong, A World of States of Affairs, p. 25.

64 Ibid, p. 5.

65 Armstrong, Universals. An Opinionated Introduction, p. 93

${ }_{67}$ Armstrong, A World of States of Affairs, p. 265.

Armstrong, Universals. An Opinionated Introduction, p. 88. 
68 Ibid, p. 88.

69 Ford, 'What happens in the Eucharist?'.

${ }^{70}$ Armstrong, A World of States of Affairs, p. 265.

${ }^{71}$ Ford, 'What happens in the Eucharist?'.

72 Armstrong, A World of States of Affairs.

73 Ibid.

74 Ibid, p. 130.

75 Ibid, p. 131.

76 Ibid, pp. 136-37.

77 Ibid, p. 130.

78 Ibid, p. 131.

79 Douglas, Ways of Knowing in the Anglican Eucharistic Tradition, pp. 168-266.

80 Douglas, Anglican Eucharistic Theology.

81 Douglas, Ways of Knowing in the Anglican Eucharistic Tradition.

82 Douglas, Anglican Eucharistic Theology.

83 The sacramental principle is based on a realist analysis and argues that God uses things of this world, such as bread and wine and water, to convey God's presence and grace.

${ }^{84}$ Robert Doyle, 'Expressing the Heart of the Gospel: A Review of the Three Orders of Holy Communion in A Prayer Book for Australia’, (Sydney: Anglican Church League, 1997),

online at http://www.acl.asn.au

85 Brian Douglas, Anglican Eucharistic Theology (A website of case studies developed as part of the degree of Doctor of Philosophy at the University of Newcastle, Australia, 2006), Case Study 4.27, available online at http://web.mac.com/brian.douglas

86 Douglas, Ways of Knowing in the Anglican Eucharistic Tradition, pp. 145-49.

87 Douglas, Anglican Eucharistic Theology. Case studies in each of the four historical periods of the Anglican eucharistic tradition exemplify both the real presence of Christ in the Eucharist and eucharistic sacrifice as moderate realist notions.

Christopher Cockworth, Evangelical Eucharistic Thought in the Church of England (Cambridge: Cambridge University Press, 1993).

Douglas, Anglican Eucharistic Theology, case studies 4.25 and 4.36.

Robert Doyle, 'Here we offer you a spiritual sacrifice' - an estimate.

94 Doyle, Expressing the Heart of the Gospel.

95 Douglas, Anglican Eucharistic Theology, Case Study 4.12.

Doyle, 'Word and Sacrament in Catholic and Evangelical Theology', p. 12. Here Doyle argues for a Word ontology as opposed to a sacramental ontology and states that Christ is present only through his Word since God does not work in the world through sacraments but only through His Word.

97 Ibid, Case Study 4.27.

Macquarrie, A Guide to the Sacraments, p. 132. Macquarrie argues that modern philosophy may well provide a way to understand what happens in the Eucharist and that such reflection may well do for the present day what transubstantiation did for a former age. 99 Douglas, Ways of Knowing in the Anglican Eucharistic Tradition.

Douglas, Anglican Eucharistic Theology. 
101 Williams, On Christian Theology, p. 4.

102 Ibid, p. 5

103 Ibid, p. 6.

104 Ibid, p. 6

105 Ibid, p. 8.

106 Lovat and Douglas, Dialogue Amidst Difference in Anglican Eucharistic Theology. 